\title{
脱墨剤の最近の動向について
}

\author{
花王株试会社化学品研究所 江戸 武, 城石 高伸
}

\section{Recent Trend and Development on Deinking Agents}

Takeshi Edo and Takanobu Shiroishi

Performance Chemicals Research Lab., Kao Corporation

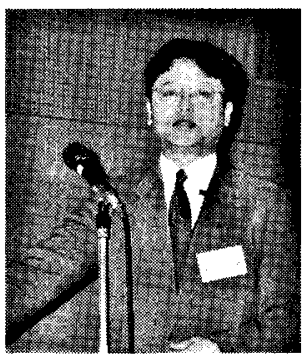

江戸 武

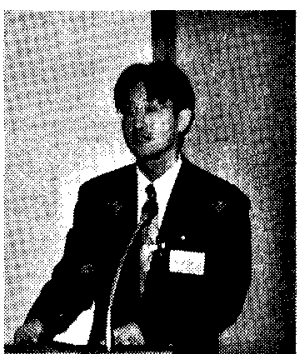

城不高伂

The deinking of old news paper (ONP) has been practiced for several decades and recognized to be important in the meaning of environmental protection. Deinking technology has been progressing chemically and/or mechanically in production of high quality paper.

The deinking agents are the chemical species which are classified in surface active agent and have an important role during flotation deinking process such as penetrability, ink coagulation ability, foaming ability, and so on. By changing the molecular configuration of the deinking agents, we succeeded in developing a new deinking agent that has a higher penetrability. The higher the penetrablity of the deinking agent, the lower the amount of nondetached ink. It is particularly effective against offset printing paper which is favored in the newsprint market in Japan. Furthermore, we could detect a direct evidence of interaction between ink and the new deinking agent by using quartz-crystal microbalance and photoacoustic spectroscopy. The new deinking agent is now in use at some deinking mills in Japan.

On the other hand, it is well known that flotation method is poor in removing fine ink particles, approximately under $10 \mu \mathrm{m}$. In spite of these particles strongly related to the products quality, they have little affinity for air bubble and making conventional flotation opeations ineffective for ink removal. In order to remove the fine ink particles efficiently, it should be coagulated during the flotation process. Considering the problems associated with fine ink particles, we have developed a new type of deinking agent. In this report we also propose a new approach for ink coagulation method by flotation deinking.

\section{1.はじめに}

地球環境保護といったグローバルな視点から，古紙 の再生利用が注目されるようになって久しい。それは 污紙の再生利用が省エネルギー, 森林資源保護, 紙原 料の確保，あるいは都市ごみ対策などと直接，または
間接的に関わっており，地球生態系の維持にとっては 非常に重要な技術だからである。

古紙の再生利用には2つの方法がある。一つは古紙 をパルパーで離解しパルプ化して，そのまま板紙等の 原料として使用する方法と, パルプ化した後に, さら に印刷インキを除去して使用する力j法である。後者の 
処理を特に脱照と呼び，この時に使用される脱墨処理 の日的に特化された界面活性剂を脱墨剂と呼ぶ。

脱黑処理のお法には大きく分けて，フロテーション 法と洗海法がある。洗浄法とは，パルプスラリーを大 量の水で肴秋してろ過脱水する操作を繰り返すことに より，遊離したインキ粒子を洗い流す方法である。一 お, フロテーション法とは, パルプスラリー中に気泡 を連続的に注人し，インキ粒子を父㣖粒子に吸着させ， その凝集体老液伯に浮上濃縮させた後, 系外に除去す るお゙法である。この润考を比較すると, フロテーショ ン法のほうが, (1)パルプの歩留りが艮い。(2)用水使用 量が少ない。(3)役備面栱が少ない。(4)トータル薬品コ ストが低い，等の长所を们しており，世界的にもフロ テーション法がけ流となってきている。

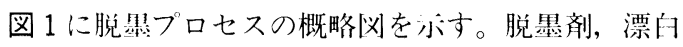
剂, アルカリなどの楽剂は離解, 熟成, 脱墨の工程で 添加される。これらの薬剂は，主にパルプ濃度の高い [程へ添加して，パルプと薬剂の接触効率を高め, さ らに処理温度をけげることにより效果が十分発揮され るようにに大されている。

\section{2. 脱墨剤の働きと種類}

脱照剂は，分了構造的には卦鎖アルキルよりなる踈 水部分と, エチレンオキサイド箈からなる親水部分を 併せもつ界自湖性剂である。

脱黑剂の界血活性:剂としての働きからみたフロテー ション法の概念刚を図 2 に亦寸。大きく分けて，パル ブからインキを別離するに程と虽離したインキを系外 へ排出する、程よりなる。脱蝫剂は通常, 離解工程で 添加され，機械艮にるセルロースからのインキの剝 離を助ける働きをする。一般にこの「程での脱墨剤添

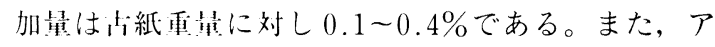
ルカリ剂を一般に併川する。

フロテーション「程では，七ルロースから剝離した インキ粒子を废还的かつ多星に除土寸るために，イン キ粒子を気泡に效摔よく吸着させなければならない。 そのためには，インキ粘径を 10３0 $\mu \mathrm{m}$ の大きさに
制御する必要があると言われており，剝離工程で数 $\mu \mathrm{m}$ に分散したインキ粒子を凝集させる働きが脱墨剂 には要求される。

このように, フロテーション法における脱墨剤は, 離解工程では古紙からのインキの剥離・分散, フロテ ーション工程ではインキの凝集といった相反する機能 の高度なバランスが必要である。

表 1 に各種の脱墨剤の分類と特徵を示した。汎用非 イオン活性剤（I）は，主として洗浄法脱墨に使用さ れる。II型の脂肪酸夕イプの脱墨剤はインキ凝集性が 強いが，インキ剥離性に劣り，さらに固形物であるた め現場での操業性も劣る。その他III〜V型に属する脱 墨剂は, 脂肪酸, 油脂, 高級アルコールのアルキレン オキサイド付加化合物である。これらは, 強い湿潤性 あるいは浸透性を持つので，インキ剝離性に優れるが フロテータにおけるインキ凝集性は脂肪酸には及ばな い。このように, 各脱墨剤にはそれぞれの特徴があり, システムや原料古紙の条件にマッチしたものを選択す る必要がある。

一方, 脱墨業界を取り巻く環境も変化してきており, それにともなって主流として使用される脱墨剤も移り 変わってきている（図 3）。脱墨の原料古紙の大部分 を占める新聞用紙について見てみると, 近年の新聞紙 軽量化 (坪量 $46 \mathrm{~g} / \mathrm{m}^{2}$ から $43 \mathrm{~g} / \mathrm{m}^{2}$ ) に伴って印刷イ ンキの古紙中の重量比率が増加している。また，印刷 方式もここ数年で，凸版印刷からオフセット印刷へ 90\%以上移行している。オフセットインキは, 凸版イ ンキに比べインキ成分中の樹脂分が多く（オフセット インキ：11〜 13\%，凸版インキ：3〜5\%)，これが熱， 酸素によって劣化（重合・固化）してインキがより強 固にパルプに付着するため䗍離が困難となる。このこ とより，新聞古紙インキの難剥離化が問題となってい る。また, 脱墨工程中の用水のクローズ化に伴って泡 トラブル等も問題となっており, フロテーション後の 泡切れも必要条件となってきている。

このような要求に伴い, 脱墨剤も汎用非イオン性の ものから, 脂肪酸, 脂肪酸誘導体, 油脂誘導体を経て,

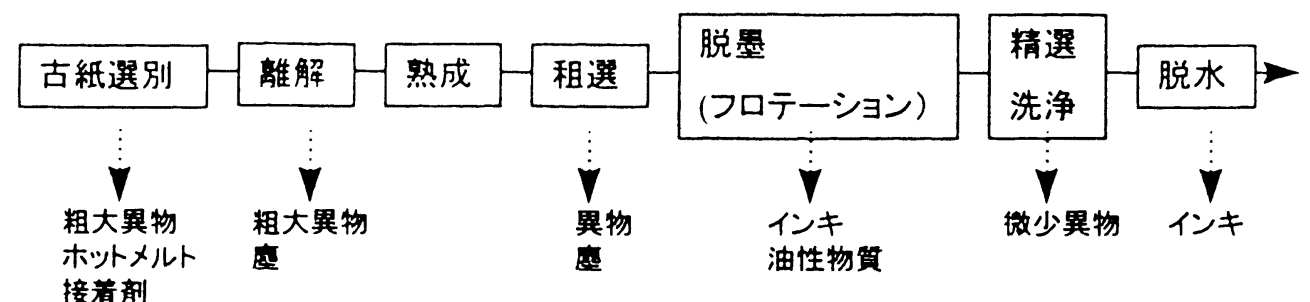

図 1 脱墨プロセス 


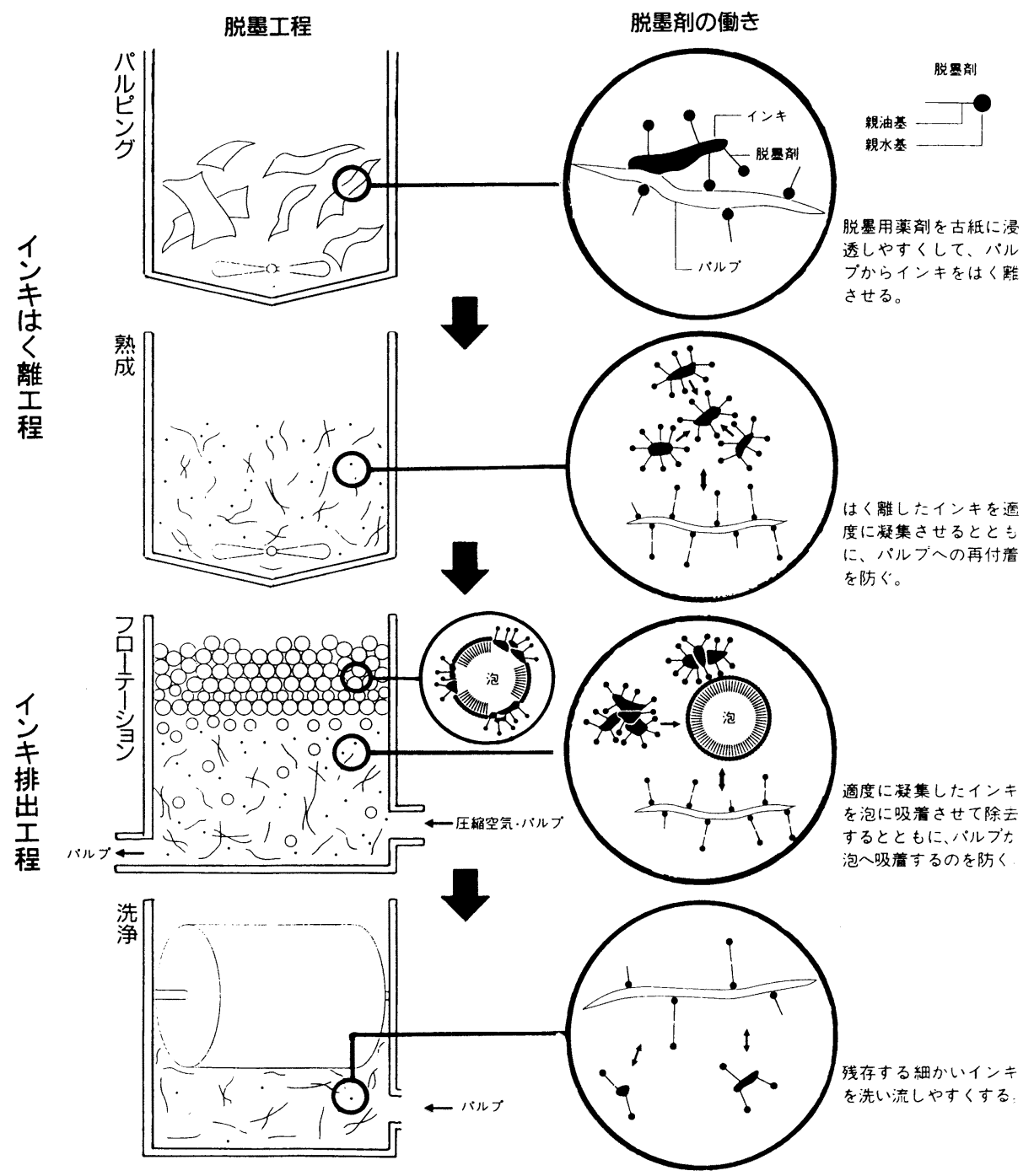

図２フロテーション法での脱黒剤の働き

表 1 各種脱墨剂の分類

\begin{tabular}{|c|c|c|c|c|c|c|c|}
\hline & & \multicolumn{4}{|c|}{ 脱 墨 性 能 } & \multicolumn{2}{|c|}{ 作 業 性 } \\
\hline & & 白色度 & $\begin{array}{l}\text { 遊 離 } \\
\text { インキ } \\
\text { 除去性 }\end{array}$ & $\begin{array}{l}\text { インキ } \\
\text { 剝離性 }\end{array}$ & $\begin{array}{l}\text { 粘着物 } \\
\text { 除去性 }\end{array}$ & $\begin{array}{ll}\text { 対 } & \text { 硬 } \\
\text { 水 } & \text { 性 }\end{array}$ & $\begin{array}{l}\text { ハンド } \\
\text { リング }\end{array}$ \\
\hline 汎用ノニオン活性剂 & I & $\triangle$ & $\triangle$ & 0 & $\triangle$ & 0 & (C) \\
\hline 脂肪酸, 脂肪酸エマルション & II & (a) & (C) & $\triangle$ & $x$ & $\times$ & $\triangle \sim X$ \\
\hline 脂肪酸誘導体 & III & 0 & $\bigcirc$ & 0 & $\bigcirc$ & 0 & (2) \\
\hline 油脂誘導体 & IV & $O \sim(0)$ & $O \sim(0)$ & $O \sim 0$ & 0 & $\bigcirc$ & (a) \\
\hline 高級アルコール誘導体 & $\mathrm{V}$ & $O \sim(0)$ & O ( () & () & (a) & 0 & (C) \\
\hline
\end{tabular}




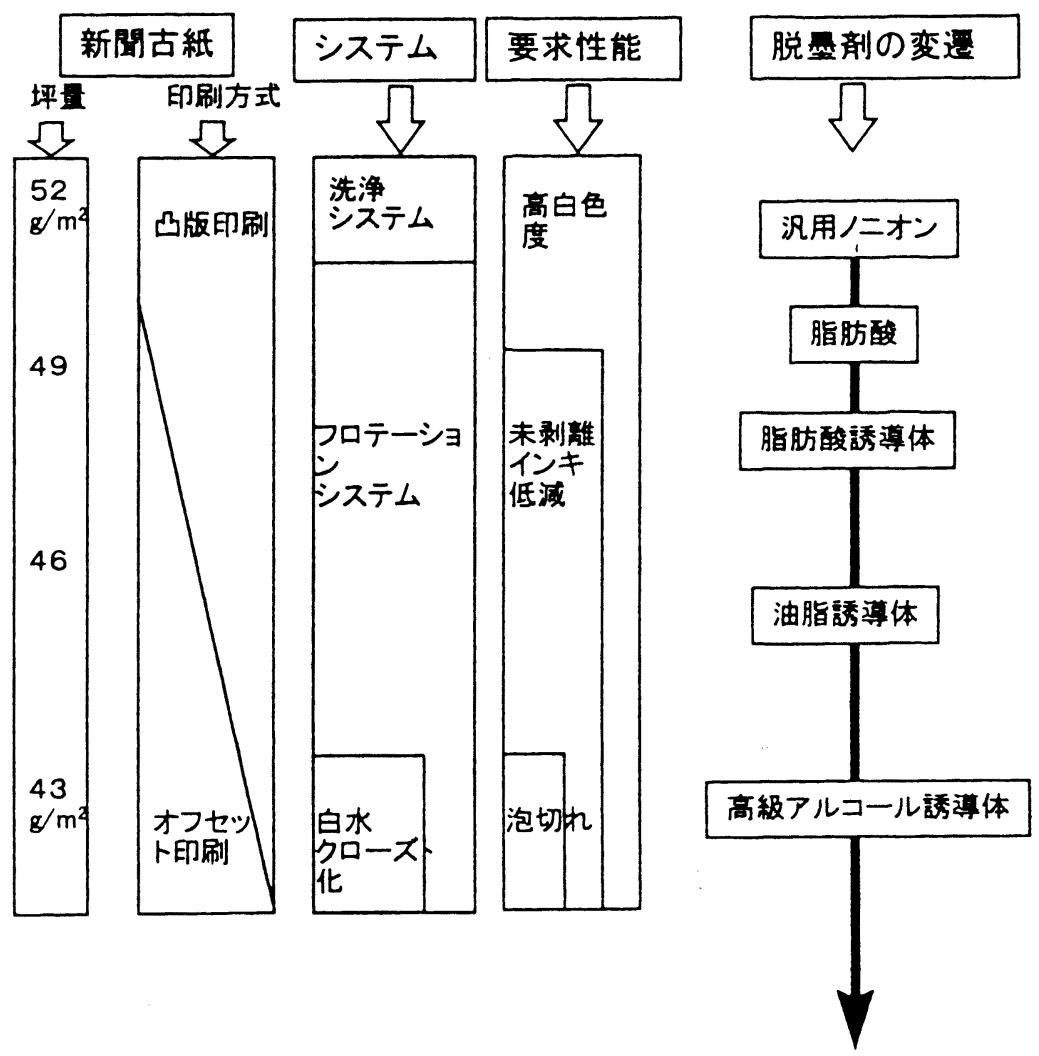

図 3 脱墨剤市場環境の変化と脱墨率の変遷

現在は高級アルコール誘導体が主流となってきている。

\section{3. 脱墨剤の開発と性能評価}

前節で，脱墨剂にはさまざまな種類があり，また市 場の要求も変化してきていることを述べた。それに対 し, 我々脱墨剤メ一カ一は界面科学的な挙動解析を基 盤として，脱墨剂分子中の柾水性の長さ，広がり，親 水基一踈水基部分のバランス調節を行うことで，ユ一 ザーニーズに合致した脱墨剤の開発を行っている。

今回は，新聞インキのオフセット化に対応した脱墨 剂の開発の例を紹介する。前節で，オフセットインキ による難剥離化が進んでいることを述べたが，図４は 凸版印刷新聞古紙とオフセット印刷新聞古紙を加熱下 で保存してモデル的に熱劣化させた古紙を，同条件で 脱墨処理した後，その保存時間と白色度，未剥離イン キの関係を比較したものである。オフセットインキは， 劣化するに従ってインキが剝離しにくく脱黒性が極端 に悪くなることがわかる。

\section{1 界面科学的考察}

オフセット化に対応する脱墨剤には，非常に高いイ ンキ剝離性が求められる。
インキ剝離の現象を界面科学的に見ると，インキ・ セルロース界面を引き剥がし，新しく脱墨剤溶液との 界面を作る仕事である（図 5)。このときに必要な工 ネルギー $W_{W}$ は次式で表せる。

$\mathrm{W}_{\mathrm{W}}=\gamma_{\mathrm{CD}}+\gamma_{\mathrm{DI}}-\gamma_{\mathrm{CI}}$

$\gamma_{\mathrm{CD}}$ : 脱墨剤溶液とセルロース繊維の界面張力

$\gamma_{\mathrm{DI}}$ : 脱墨剤溶液とインキとの界面張力

$\gamma_{\mathrm{CI}}$ : インキとセルロース繊維との界面張力

剝離をし易くすることは $\mathrm{W}_{\mathrm{W}}$ を小さくすることで ある。 $\gamma_{\mathrm{CD}}, \gamma_{\mathrm{C} 1}$ はほぼ一定とすると, この式よりイン キと脱墨剤溶液との界面張力 $\left(\gamma_{\mathrm{DI}}\right)$ を小さくすればイ ンキ剝離に必要なエネルギーが小さくなることが判る。 さらに,この界面張力 $\gamma_{\mathrm{DI}}$ は以下のような式で表せる。

$\gamma_{\mathrm{DI}}=\gamma_{\mathrm{D}}+\gamma_{\mathrm{I}}-2 \varepsilon_{\mathrm{DI}}$

$\gamma_{\mathrm{D}}$ : 脱墨剤溶液の表面張力

$\gamma_{1}$ : インキの表面張力

$\varepsilon_{\mathrm{DI}}$ : 脱墨剂溶液とインキとの分子間力

ここで， $\gamma_{1}$ は一定であるから，脱墨剤溶液の表面 張力を小さくするか, 脱墨剤溶液とインキとの分子間 引力を大きくすれば $\gamma_{\mathrm{DI}}$ が小さくなり，インキの剝離 が容易になることがわかる。 

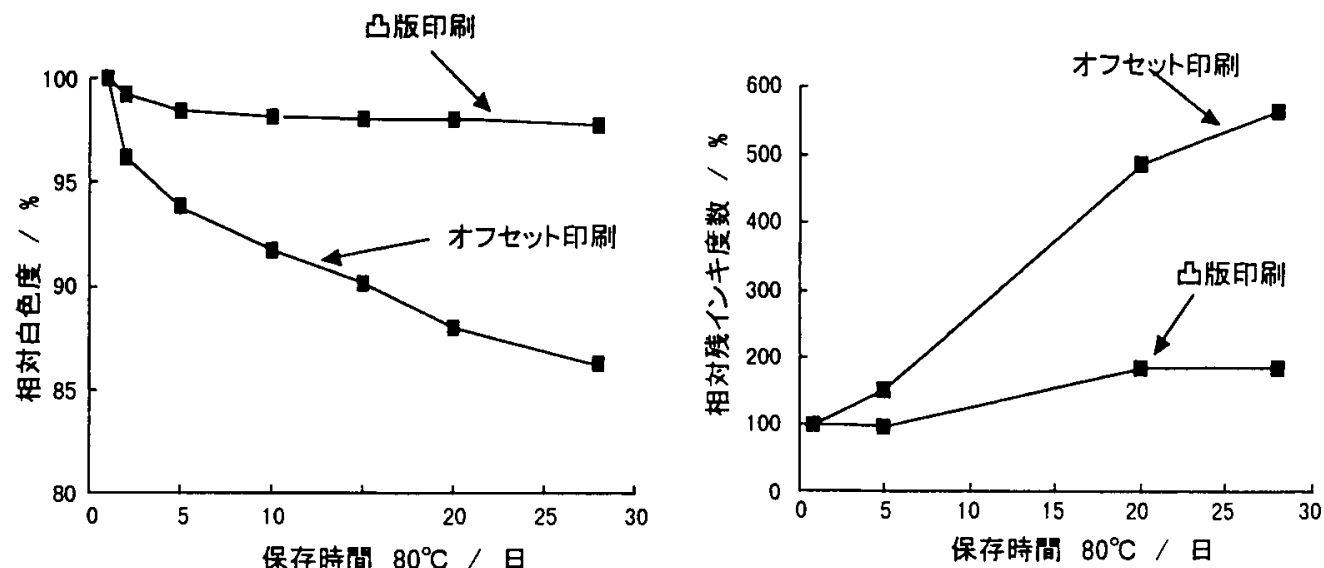

図 4 新聞占紙の劣化度合いと脱墨性の相関

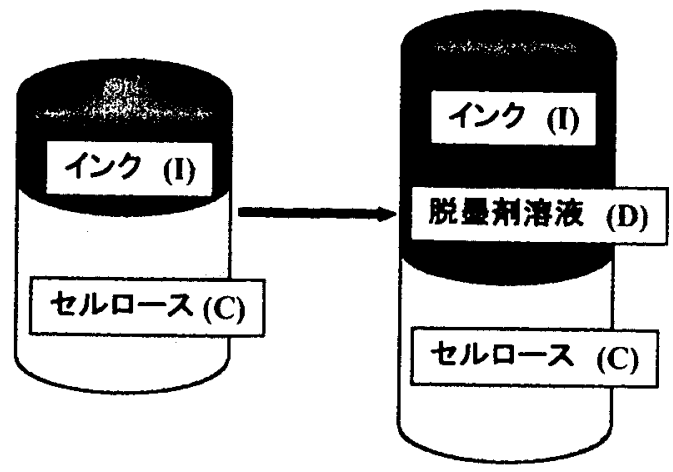

図 5 インキ剥離のモデル

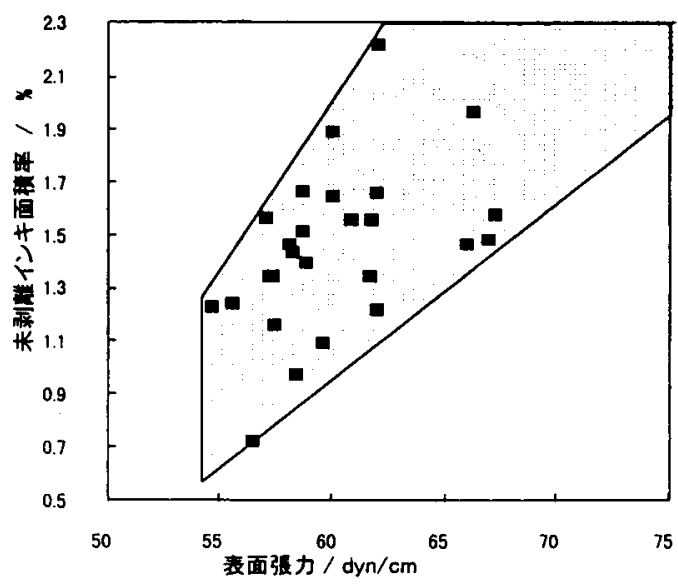

図 6 インキ剝離と表面張力

具体的には，インキへの吸着・浸透性が強く，表面 活性能力の大きな郕が求められる。図 6 はさまざまな 脱思剂の表面張力とインキ剥離性の相関を示したもの である。表面張力の低い脱墨剤物は，一般にインキ剥 離性が良好であり，表面張力の低下能がインキ剥離に
大きく関わっていることがわかる。

一般に, 従来の脱榡郕で強い浸透性をもつものは, フロテーション時の泡レベルが高く, 泡切れが悪いた め泡トラブルを起こす傾们にあった。しかし，我々は， 浸透性の高い基本骨格を維持しつつ，特殊な分子配列 を導入することで泡切れ性を改良できることを見出し た。そこでここの新しい構造をもつ化合物について， インキへの需れ性, 吸着性, 及びインキへの浸透性と いった評価をもとに新規脱墨剂の最適化を行ったので 紹介したい。なお，本稿では，以前は主流的な脱墨郕 であった油脂誘導体を対照として比較を示す。

\section{2 濡れ性及び吸着性}

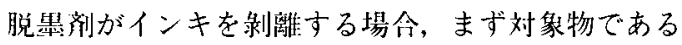
インキ・セルロース界面へ吸着し濡れ広がり，表面張 力を引き下げなければならない。

脱墨㘊溶液の劣化インキ表洎卜接触角を测定した ところ，新規脱墨剤が $24 \pm 2$, 油脂誘導体が $32 \pm 2$ で

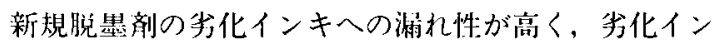
キへの親和性が高いことがわかる。

また，さらに水晶振動子法による劣化インキ表面へ の脱疁剤の吸着量を測定した (図7)。この結果，新 規脱墨率は油脂誘導体より吸着速度が速く, 吸着量も 約 1.5 倍であることがわかる。

\section{3 浸 透 性}

脱墨戍の少化インキ内への浸透性を光音響分光法に よって测定した（図 8)。この力法により，インキ表 面上に滴下した脱墨郕がインキ表面から深さ力向にど のくらい深く，さらにどのくらい速く浸透するかを見 ることができる。新規脱柾㘊は油脂誘導体に比べてよ り深く劣化インキ小に漫透し, また, 初期浸透速度も 50 倍である。 


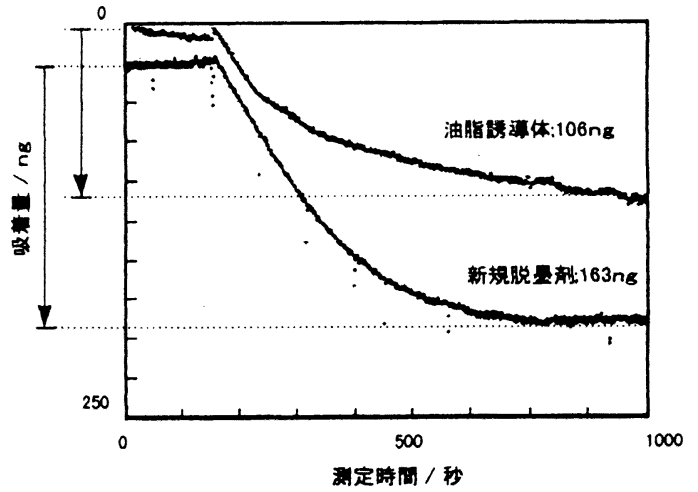

図 7 水疁拨動子法による劣化インキへの脱墨剂吸着 星の測管

このように，新規脱睲剂は吸着性，浸透性のいずれ も新規脱墨剂が艮好であり，劣化オフセットインキと の親利性:に優れていることがわかる。

3.4 脱墨性一ラボスケール

以上の界面科兴的呼体を経て最適化された新規脱墨 剂について，笑際にラボスケールで脱墨試駼を行った 上ころ目色度，木䟝離インキ軍ともに従来の脱墨剤よ り菖いレベルにあり，難制離インキに対して十分な効 果を小寸ことがわかった（図 9，10）。

\section{5 脱墨性一実機スケール}

従来の油脂㮩導体型脱量剂を使用していた脱墨工場

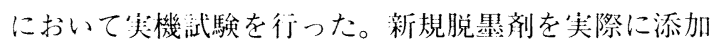
した武験期間では，明らかにインキ剥離性が向上し，

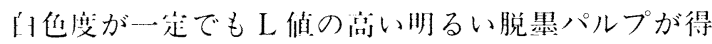
られ，ラボでの誹価結果を裏付けていた（図 11，12）。 また，フロテータ後の沧切扎も圤好であったことが確 認された。

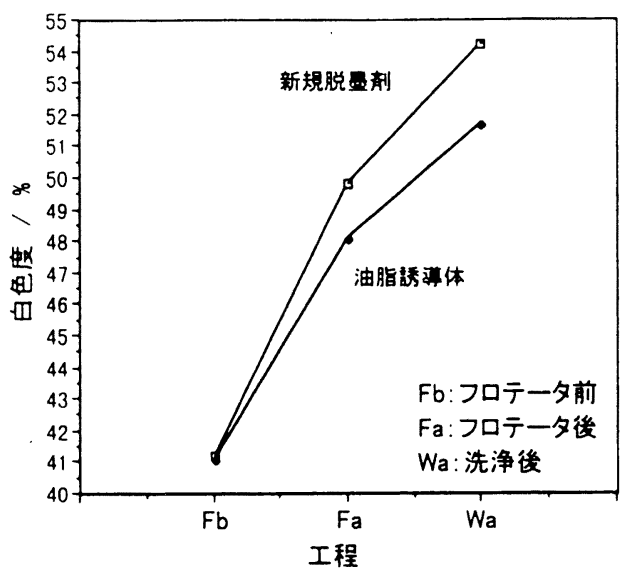

図 9 父脱照に程におけるは色度一ラボ武験

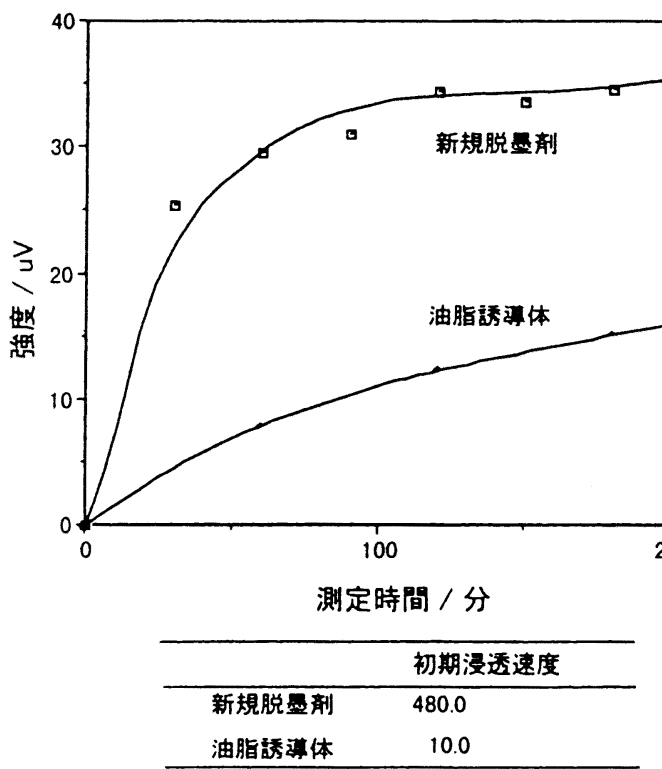

図 8 光音響分光法による脱墨剂のインキへの浸透性 の測定

今回は，特に剥離に注目した解説を行ったが，脱墨 剂の開発は, 機械的性質（例えばフロテー夕起泡量, 気泡径, 処理時間) や, 溶液特性 ( $\mathrm{pH}$, 温度, 硬度) 等の変動因子を考慮して行う必要がある。

\section{4. 今後の脱墨剤の開発方向}

この新規脱墨剤はその優れな性能によって，現在は 複数の製紙会社で使用されている。今後もこのような 強いインキ剝離型の脱墨剤が主流を占めると思われる。 しかし，一方ではこれらは脱墨工程内でのインキの微 細化を進めることが賏念される。よって, 今後さらに

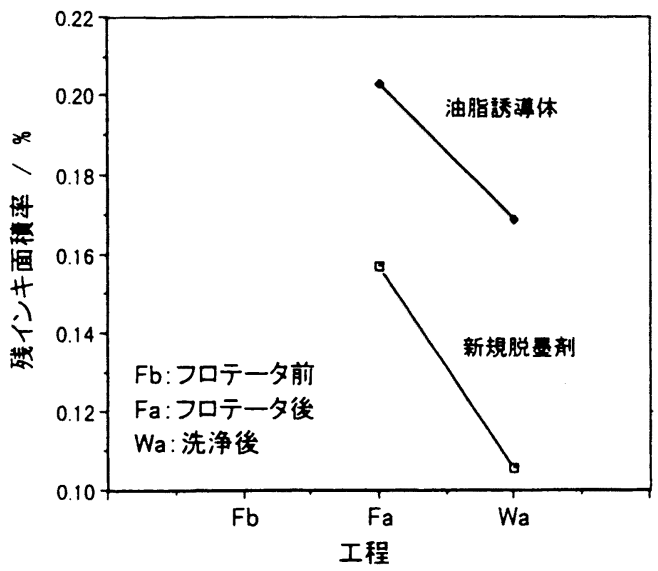

図 10 各工程の残インキ面積率ーラボ試験 


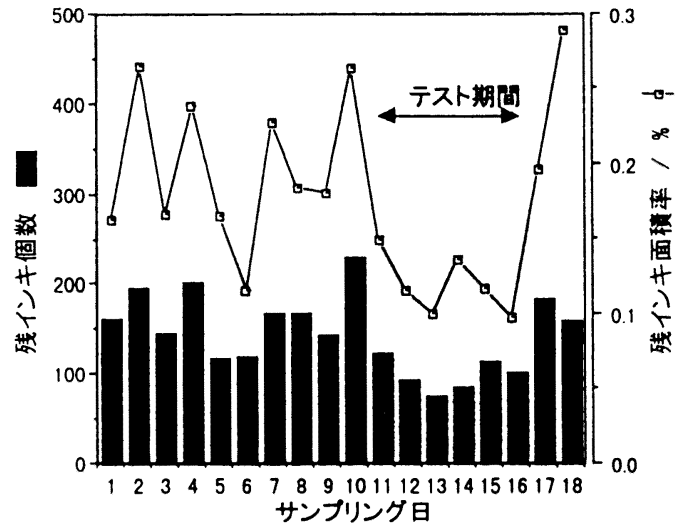

図 11 残インキー実機試験

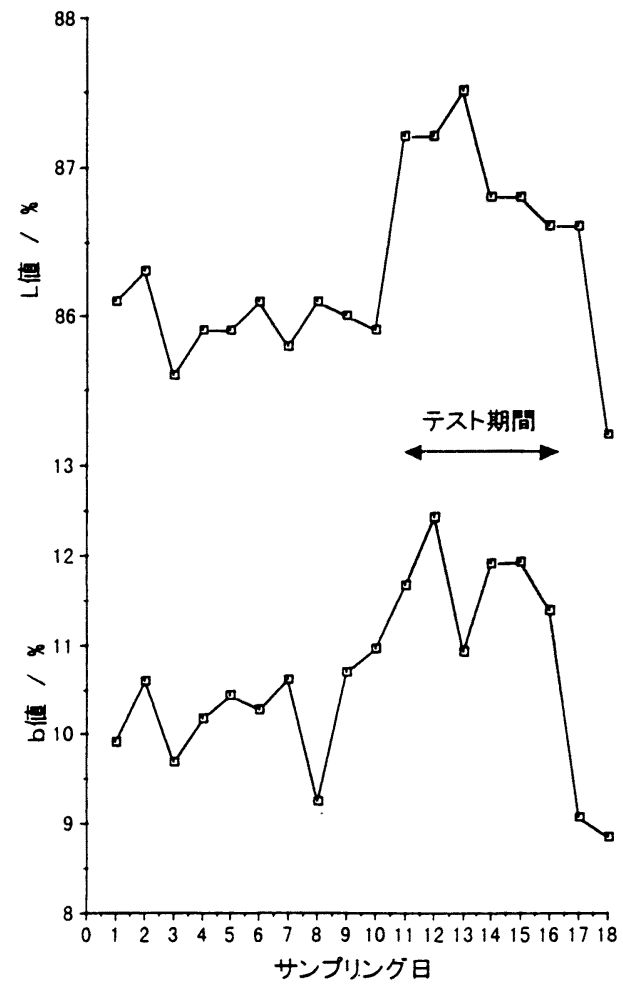

図 12 脱墨パルプ品質一実機試験

高い脱墨パルプ品質を得るためには，剝離インキをよ り効率的に凝集してフロテータで除去するインキ除去 性の良い脱墨剤の開発が急務であると考えている。

従来, 微細なインキは白色度の低下に大きく影響し ていると言われてきた。図 13 は粒子径が白色度に及 ぼす影響を示している。これによると，大きな粒径 (50 $\mu \mathrm{m})$ はその存在量が増えても白色度に大きな影 響はあまり無いが，粒径が小さくなるにつれてその影 響が大きくなり, 粒径 $2 \mu \mathrm{m}$ のものは $0.5 \%$ 存在量

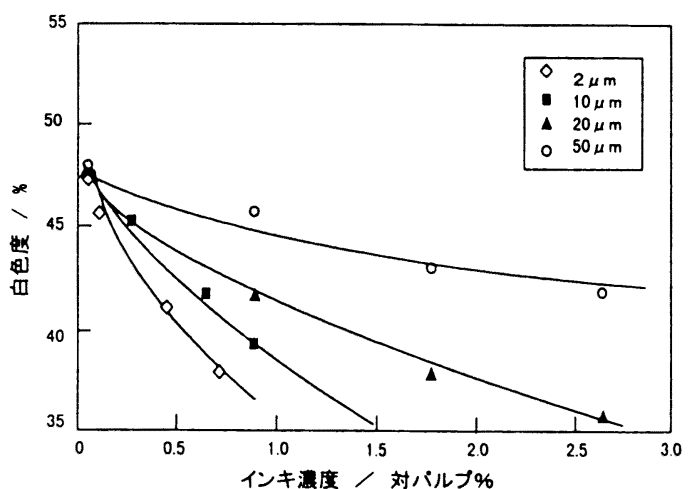

図 13 各粒径域のインキ量と色度の関係

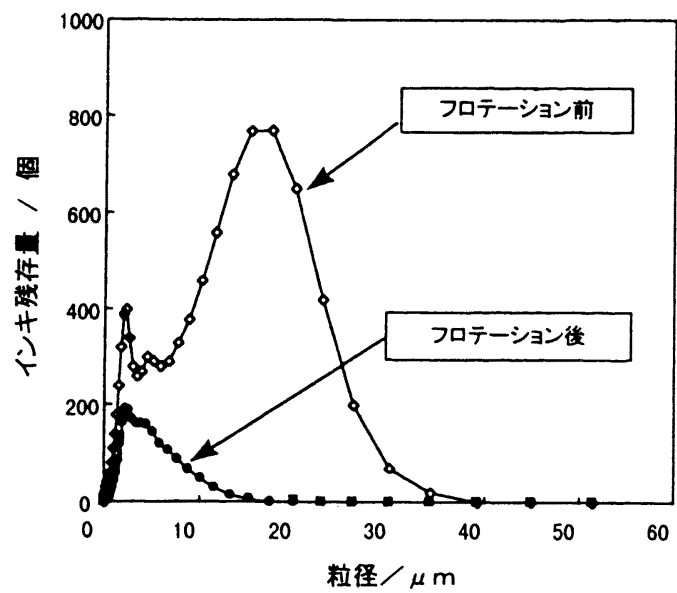

困 14 フロテーション前後のインキ粒径分布

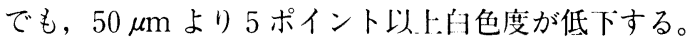
最近, 我々は微細インキの測定システムを構築し, これまで測定不能であった微細領域のインキ粒径を測 定することを可能とした。図 14 は現行の脱墨剤でフ ロテーションを行い, その前後のインキ粒径分布をそ の装置によって測定したものである。10３0 $\mu \mathrm{m}$ 領域 のインキはほぼ完全に除去されているのに対し，4 $\mu \mathrm{m}$ 以下の微細インキは現行の脱墨剂では困難である ことを確認した。現在我々は，この測定法を駆使して， 微細インキを効率的に除去する全く新しい夕イプの凝 集脱墨郕についての開発を進めているところである。

\section{参考文献}

1）岡田英三郎：紙パ技協誌, 47 (1) 116, 1993

2) F. Togashi and E. Okada : TAPPI Proceedings, 1989 Pulping Conference, p. 343

3）高橋広通：油化学, 42 (10) 834, 1993

4）高橋広通：紙パルプ技術夕イムス，38（5）25, 1995 